Research Article

\title{
Reticulated Open-Celled Zinc Oxide Ceramic Foams: Manufacturing, Microstructure, Mechanical, and Thermal Properties
}

\author{
Ulf Betke $\mathbb{D}$ and Michael Scheffler \\ Otto-von-Guericke-University Magdeburg, \\ Institute for Materials and Joining Technology-Nonmetallic Inorganic Materials and Composites, Große Steinernetischstraße 6, \\ 39104 Magdeburg, Germany
}

Correspondence should be addressed to Ulf Betke; ulf.betke@ovgu.de

Received 7 January 2019; Accepted 4 April 2019; Published 2 May 2019

Academic Editor: Carlos R. Rambo

Copyright (c) 2019 Ulf Betke and Michael Scheffler. This is an open access article distributed under the Creative Commons Attribution License, which permits unrestricted use, distribution, and reproduction in any medium, provided the original work is properly cited.

\begin{abstract}
Open-celled zinc oxide ceramic foams were prepared by the polymer sponge replication (Schwartzwalder) technique from aqueous $\mathrm{ZnO}$ dispersions with $\mathrm{Sb}_{2} \mathrm{O}_{3}$ and $\mathrm{Bi}_{2} \mathrm{O}_{3}$ as sintering additives, and mechanically stable $\mathrm{ZnO}$ foams with an average porosity of $93.6 \%$ were obtained. Their microstructure consists of $\mathrm{ZnO}$ grains with a Bi-containing grain boundary phase together with a $\mathrm{Zn}-\mathrm{Sb}-\mathrm{O}$ secondary phase with spinel structure. The obtained $\mathrm{ZnO}$ ceramic foams were characterized with respect to their morphology by computed tomography; in addition, the compressive strength and the thermal conductivity were determined, and the data were applied for modelling of the mechanical and thermal properties of the bulk $\mathrm{ZnO}$ strut material.
\end{abstract}

\section{Introduction}

Open-celled ceramic foams are used within several technological fields; with respect to the quantity, the most prominent applications are filter materials for metal melts in casting or catalyst supports [1]. Ceramic foams for the above-mentioned applications are manufactured on an industrial scale by the polymer sponge replication process established by Schwartzwalder and Somers in 1961 [2]. This results in a macrocellular foam-like structure similar to that of the polymeric sponge used as template in this process. A variety of cellular ceramic materials has been produced by this technique, an overview can be found in references $[3,4]$. However, to our knowledge, no zinc oxide foams have been prepared by the sponge replication process yet.

Zinc oxide is a semiconductor material, which crystallizes in the wurtzite structure type in analogy to aluminum nitride or silicon carbide, for example. Therefore, it belongs to the class of adamantine compounds with a basic all-tetrahedral coordination of cations and anions [5]. As a consequence of this simple structure type, the phonon conductivity is high, which results in a good thermal conductivity for adamantine compounds [6]. Consequently, pure zinc oxide has a thermal conductivity of $50 \mathrm{~W} \cdot \mathrm{m}^{-1} \cdot \mathrm{K}^{-1}$ at room temperature, which is high for an oxidic compound [7].

A typical application for $\mathrm{ZnO}$-based ceramics is varistors, which have a distinct nonohmic electrical conductivity, i.e., a very low conductivity below a characteristic breakthrough voltage and can be used for overvoltage protection [8]. The nonohmic properties of $\mathrm{ZnO}$-based varistors are a complex function of the microstructure, for example, the amount and distribution of secondary phases $[9,10]$. Common additives for sintering and microstructural control in these varistor ceramics are the antimony and bismuth oxides $\mathrm{Sb}_{2} \mathrm{O}_{3}$ and $\mathrm{Bi}_{2} \mathrm{O}_{3}$ [11]. Bismuth oxide forms a low-melting eutectic together with $\mathrm{ZnO}$ and promotes an effective low-temperature liquid phase sintering mechanism resulting in a distinct $\mathrm{ZnO}$ grain growth. On the contrary, antimony oxide reacts with $\mathrm{ZnO}$ to a ternary $\mathrm{Zn}-\mathrm{Sb}-\mathrm{O}$ phase, which restricts the $\mathrm{ZnO}$ grain growth by a pinning mechanism [12]. Consequently, the $\mathrm{Sb} / \mathrm{Bi}$ ratio in the ceramic raw material is essential for the final microstructure and the electrical properties of $\mathrm{ZnO}$ ceramics. 
In the present work, the established polymer sponge replication-Schwartzwalder-process has been adopted for the manufacturing of zinc oxide ceramic foams. As sintering aids, $\mathrm{Sb}_{2} \mathrm{O}_{3}$ and $\mathrm{Bi}_{2} \mathrm{O}_{3}$ were used in a fixed molar ratio of $2: 1$. The obtained foams were characterized with respect to their microstructure (SEM and phase composition by XRD) and their macroscopic properties mechanical strength and thermal conductivity as a function of the total porosity and morphology. Finally, the bulk properties of the $\mathrm{ZnO}$ strut material were extrapolated from the obtained data by applying established structure (porosity)-property relations.

\section{Materials and Methods}

2.1. Powder Preparation. The ceramic raw powder was prepared by ball-milling a dispersion of $200 \mathrm{~g}$ zinc oxide $\left(d_{50}=0.2 \mu \mathrm{m}\right.$, Harzsiegel Standard, Norzinco $\mathrm{GmbH}$, Goslar, Germany), $7.28 \mathrm{~g} \mathrm{Sb}_{2} \mathrm{O}_{3}$ (1.0 mol\% w. r. t. $\mathrm{ZnO}$ ), and $5.82 \mathrm{~g}$ $\mathrm{Bi}_{2} \mathrm{O}_{3}(0.5 \mathrm{~mol} \%$ w. r. t. $\mathrm{ZnO})$ in $300 \mathrm{~mL}$ ethanol for $4 \mathrm{~h}$. A planetary ball mill (PM 400, Retsch $\mathrm{GmbH}$, Haan, Germany) operating at a milling speed of $300 \mathrm{rpm}$ and equipped with two $250 \mathrm{~mL}$ alumina grinding bowls and 50 alumina balls each with $d=10 \mathrm{~mm}$ was used. Afterward, the $\mathrm{ZnO}-\mathrm{Sb}_{2} \mathrm{O}_{3}-\mathrm{Bi}_{2} \mathrm{O}_{3}$ powder was collected by vacuum filtration and dried at $100^{\circ} \mathrm{C}$.

2.2. Dispersion Preparation. The ceramic dispersion for foam manufacturing was prepared by adding $100 \mathrm{~g}$ of the $\mathrm{ZnO}-\mathrm{Sb}_{2} \mathrm{O}_{3}-\mathrm{Bi}_{2} \mathrm{O}_{3}$ oxide mixture and $1.0 \mathrm{~g}$ ethanolammonium citrate deflocculant (Dolapix CE64, Zschimmer \& Schwarz Chemie GmbH, Lahnstein, Germany) to $26.5 \mathrm{~mL}$ distilled water. The mixture was homogenized for $15 \mathrm{~min}$ using a planetary centrifugal mixer (THINKY Mixer ARE250, THINKY Corp., Tokyo, Japan) operated at $2000 \mathrm{rpm}$. Afterward, $1.5 \mathrm{~g}$ polyvinylalcohol binder (Optapix PA 4G, Zschimmer \& Schwarz Chemie $\mathrm{GmbH}$ ) and $0.1 \mathrm{~g}$ polyalkylene glycolether defoamer (Contraspum K1012, Zschimmer \& Schwarz Chemie $\mathrm{GmbH}$ ) were added to the dispersion followed by a second mixing step for $15 \mathrm{~min}$ at $2000 \mathrm{rpm}$. The resulting dispersion has a solid content of 77.5 wt. $\%$, which is 37.9 vol. $\%$.

2.3. $\mathrm{ZnO}$ Foam Manufacturing. For the $\mathrm{ZnO}$ foam, manufacturing reticulated polyester polyurethane (PU) foams (SP30P20R, Koepp Schaum GmbH, Oestrich-Winkel, Germany) with 20 pores per linear inch (ppi) and a cubic geometry with $20 \mathrm{~mm} \times 20 \mathrm{~mm} \times 20 \mathrm{~mm}$ were used as template structure. The PU foams were completely immersed into the $\mathrm{ZnO}$ dispersion and subsequently freed from the excess amount by manual squeezing of the foam template until its weight reached approximately $2.4 \mathrm{~g}$ (corresponding to $\approx 93.5 \%$ porosity in the final foam piece after sintering). After drying under ambient conditions, the $\mathrm{PU}$ template was removed thermally in three steps $\left(110^{\circ} \mathrm{C} / 2 \mathrm{~h}, 250^{\circ} \mathrm{C} / 3 \mathrm{~h}, 400^{\circ} \mathrm{C} / 3 \mathrm{~h}\right.$, heating/cooling rate $1 \mathrm{~K} \cdot \mathrm{min}^{-1}$ ) in a circulating air furnace (KU 40/04/A, THERMCONCEPT Dr. Fischer GmbH, Bremen, Germany). Afterward, the samples were densified at $1100^{\circ} \mathrm{C}$ for $3 \mathrm{~h}$ in air (heating rate of $3 \mathrm{~K} \cdot \mathrm{min}^{-1}$ ) using a $30 \mathrm{~L}$ sintering furnace (LH 30/14, Nabertherm GmbH, Lilienthal, Germany). For thermal conductivity measurements, rectangular PU templates with a dimension of $50 \mathrm{~mm} \times 50 \mathrm{~mm} \times 20 \mathrm{~mm}$ were coated with the $\mathrm{ZnO}$ dispersion; the excess of slurry was extruded with a roller press to reach a total weight of $15 \mathrm{~g}$ for the coated PU foam. Template removal and sintering were performed as described above.

2.4. $\mathrm{ZnO}$ Foam Characterization. The total porosity of the foams ( $V_{\text {pores }} / V_{\text {foam }}$ ) was calculated from the geometric foam density, which is the foam mass $m_{\mathrm{f}}$ divided by the geometric foam volume $V_{\mathrm{f}}$, and the skeletal density of the strut material. A skeletal density of $5.65 \mathrm{~g} \cdot \mathrm{cm}^{-3}$ was calculated for the $\mathrm{ZnO}$ material by the rule of mixture. As an approximation, the density and weight fraction of $\mathrm{ZnO}, \mathrm{Sb}_{2} \mathrm{O}_{3}$, and $\mathrm{Bi}_{2} \mathrm{O}_{3}$ according to the initial starting powder were used. The strut porosity ( $\left.V_{\text {strut pores }} / V_{\text {struts }}\right)$ and the strut pore volume were calculated from the dry, buoyant, and water-filled weight of the foams as determined by the water immersion/Archimedes' method according to the DIN EN 623-2:1993-11 standard [13]. To separate the porosity being present in the ceramic phase the volume of the hollow strut cavity caused by the removal of the PU foam template was subtracted from the overall strut porosity results. The volume of the hollow strut cavities was estimated from the average PU template weight of $0.244 \mathrm{~g}$ for a $8 \mathrm{~cm}^{3}$ foam piece and a PU skeletal density of $1.1 \mathrm{~g} \cdot \mathrm{cm}^{-3}$ according to He-pycnometry. A volumetric shrinkage of the $\mathrm{ZnO}$ foam samples of $41 \%$ was considered in this estimation. For the porosity characterization, 37 specimens were analyzed, and the results were averaged.

The quantitative phase composition of the $\mathrm{ZnO}$ strut material was determined by powder X-ray diffraction (PANalytical X'Pert Pro Bragg-Brentano diffractometer, Co$\mathrm{K} \alpha_{1} / \alpha_{2}$ radiation) after ball-milling the respective sample for $5 \mathrm{~min}$ at $300 \mathrm{rpm}$. The grinded powder was filled into a backloading sample holder and measured in a $\theta / \theta$ reflection geometry with a $2 \theta$ range from $10^{\circ}$ to $160^{\circ}$. The obtained diffraction patterns were analyzed by the Rietveld technique using the Topas Academic 5 program package $[14,15]$.

The thermal conductivity of the $\mathrm{ZnO}$ foams was determined using the transient plane source (TPS) technique and a TPS $2500 \mathrm{~S}$ device (Hotdisk SE, Gothenburg, Sweden) by placing the sensor in between two $42 \mathrm{~mm} \times 42 \mathrm{~mm} \times 17 \mathrm{~mm}$ foam samples with previously sanded surfaces [16]. A TPS sensor with $9.908 \mathrm{~mm}$ in diameter and a heating power of $200 \mathrm{~mW}$ for a $10 \mathrm{~s}$ measurement was used. The thermal conductivity was calculated from the sensor temperature change [17].

The compressive strength was determined using a TIRAtest 2825 universal testing machine and circular loading plates with $150 \mathrm{~mm}$ in diameter and a crosshead speed of $1 \mathrm{~mm} \cdot \mathrm{min}^{-1}$ (TIRA GmbH, Schalkau, Germany). To ensure a more homogeneous load on the samples, a cardboard piece with $1 \mathrm{~mm}$ thickness was placed between the foam and the loading plates. From the obtained data, the maximum force was extracted and used for the calculation of the compressive strength. The results of 35 specimens were evaluated using a two-parameter Weibull distribution and the Visual-XSel 14 program package [18, 19]. From this 
distribution, the average compressive strength $\sigma_{\mathrm{fc}}$ (Weibull scale parameter) together with the modulus $m$ (Weibull shape parameter) as a measure of the Weibull distribution's width were deduced.

The microstructure of selected specimens was characterized by scanning electron microscopy using a XL30 ESEM-FEG microscope (FEI/Philips, Hillsboro/OR, USA) equipped with a secondary electron (SE) and backscattered electron (BSE) detector. The grain size distribution in the $\mathrm{ZnO}$ strut material was determined from the BSE micrographs by manually measuring the dimension of 150 individual grains. The elemental composition of the $\mathrm{ZnO}$ strut material was analyzed by energy dispersive $\mathrm{X}$-ray spectroscopy (EDAX-AMETEK GmbH, Weiterstadt, Germany). Beforehand, the grinded sample material was uniaxially pressed at $30 \mathrm{MPa}$ for $2 \mathrm{~min}$ into slabs, which were used for the EDS characterization. Nine EDS spectra were recorded at different positions on the sample and were used for the subsequent elemental analysis.

Micro-computed tomography $(\mu-\mathrm{CT})$ was applied for the characterization of the foam macrostructure. For a measurement using a nanotom $S$ tomograph (Phoenix/GE Sensing \& Inspection, Wunstorf, Germany), a set of 1080 radiographs with a resolution of $2304 \times 2304$ pixels was collected using an exposure time of $750 \mathrm{~ms}$ per image. The distances between detector and X-ray source (FDD) and between object and X-ray source (FOD) were adjusted to result in a voxel size of $(9 \mu \mathrm{m})^{3}$. Data acquisition and reconstruction were performed with the Phoenix Datos |X 2.0 software package (Phoenix/GE Sensing \& Inspection). For the calculation of the strut and cell size distributions, the CTAnalyser 1.17 program package was used after applying a $2 \times 2$ voxel binning to an effective voxel size of $(18 \mu \mathrm{m})^{3}$ (CTAn, Skyscan/Bruker microCT, Kontich, Belgium). The import of the collected CT data into the CTAn software, and the differential thresholding-based binarization procedure preceding the actual calculations were performed as described elsewhere [20]. The cell size and strut thickness distributions were calculated after filling the hollow strut cavities by performing a morphological closing operation in CTAn using a round kernel with $r=10 \mu \mathrm{m}$ as described in a previous study [21]. The strut filament thickness distribution was calculated without closing of the hollow strut cavities.

\section{Results and Discussion}

The dispersion of the $\mathrm{ZnO}-\mathrm{Sb}_{2} \mathrm{O}_{3}-\mathrm{Bi}_{2} \mathrm{O}_{3}$ powder mixture in water using an ethanolammonium citrate-based deflocculant was successful with respect to the rheological behavior up to a solid content of $77.5 \mathrm{wt} . \% / 37.9$ vol.\%. The obtained dispersion possessed the desired shear-thinning flow behavior and a viscosity suitable for the successful manufacturing of cellular $\mathrm{ZnO}$ ceramics by the polymer sponge replication technique $[22,23]$.

3.1. Microstructure of $\mathrm{ZnO}$ Ceramic Foams. After sintering, mechanically stable $\mathrm{ZnO}$ ceramic foams were obtained which showed an intense yellow color (Figure 1). This is

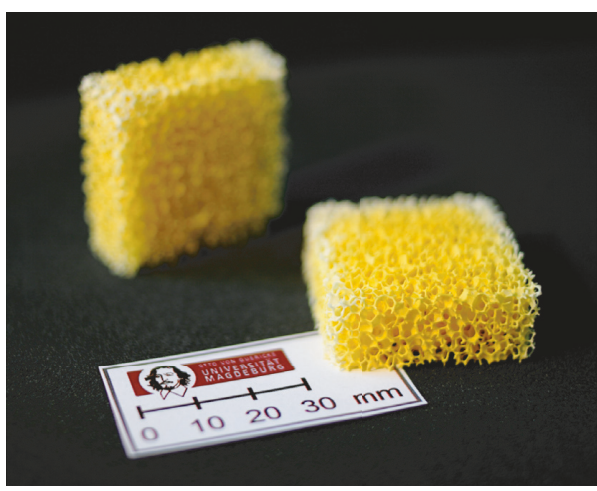

FIgURE 1: Open-cellular zinc oxide ceramic foams with a pore count of 20 ppi and $93.6 \%$ total porosity after sintering at $1100^{\circ} \mathrm{C}$. The yellow color is a consequence of structural defects in the $\mathrm{ZnO}$ lattice (oxide vacancies and interstitial zinc atoms).

characteristic for zinc oxide materials and can be attributed to the presence of structural defects like oxide vacancies and interstitial zinc atoms in the hexagonal wurtzite structure of $\mathrm{ZnO}[8,24]$.

In the SEM micrographs of the strut material, a dense microstructure of well-sintered $\mathrm{ZnO}$ grains was observed (Figures 2(a) and 2(b)). The bright regions in the BSE images found at the grain boundaries indicate a homogeneously distributed Bi-containing secondary phase (Figures 2 (b) and $2(c))$. In accordance with literature data, this $\mathrm{Zn}-\mathrm{Bi}-\mathrm{O}$ grain boundary phase is formed during the liquid phase sintering process from the eutectic mixture of $\mathrm{ZnO}$ and the sintering aid $\mathrm{Bi}_{2} \mathrm{O}_{3}$ melting at $750^{\circ} \mathrm{C}[25,26]$. An antimony containing phase is found in form of octahedral crystallites with $0.3 \mu \mathrm{m}$, on average, in diameter (Figure 2(e)), which can be assigned to the cubic polymorph of the $\mathrm{Zn}_{7} \mathrm{Sb}_{2} \mathrm{O}_{12}$ phase with spinel structure $[26,27]$.

Moderate $\mathrm{ZnO}$ grain growth from $0.2 \pm 0.07 \mu \mathrm{m}$ in the starting powder to an average of $2.6 \pm 0.9 \mu \mathrm{m}$ in the foam strut material was found after sintering at $1100^{\circ} \mathrm{C}$ (Figure 2(d)). This is significantly lower than grain sizes of $6 \mu \mathrm{m}$ to $8 \mu \mathrm{m}$ as reported in studies of dense $\mathrm{ZnO}$ ceramics made from similar powder mixtures [11, 28]. Most likely, this is a consequence of the pressureless preparation of the respective foam green bodies and the pressureless sintering procedure.

Powder X-ray diffraction reveals $89.0 \mathrm{wt}$ \% of hexagonal wurtzite- $\mathrm{ZnO}$ as the main phase being present in the strut material (Figure 3, Table 1). As secondary phases, $10.3 \mathrm{wt} . \%$ of a cubic $\alpha-\mathrm{Zn}_{7} \mathrm{Sb}_{2} \mathrm{O}_{12}$ spinel phase and $0.7 \mathrm{wt} . \%$ tetragonal $\beta-\mathrm{Bi}_{2} \mathrm{O}_{3}$ were found. Interestingly, the thermodynamically stable orthorhombic $\beta$-polymorph of $\mathrm{Zn}_{7} \mathrm{Sb}_{2} \mathrm{O}_{12}$ as well as a $\mathrm{Zn}(\mathrm{BiSb})_{3} \mathrm{O}_{7}$ pyrochlore phase were not detected. This is in contrast to other studies of the phase evolution in the $\mathrm{ZnO}$ $\mathrm{Sb}_{2} \mathrm{O}_{3}-\mathrm{Bi}_{2} \mathrm{O}_{3}$ system. For compact $\mathrm{ZnO}$ ceramics prepared under comparable conditions (sintering at $1100^{\circ} \mathrm{C}, \mathrm{Sb} /$ $\mathrm{Bi}=2$ ), a pyrochlore phase and/or $\beta-\mathrm{Zn}_{7} \mathrm{Sb}_{2} \mathrm{O}_{12}$ were reported as secondary phases $[11,26,29]$.

In this context, the polymorphism of $\mathrm{Zn}_{7} \mathrm{Sb}_{2} \mathrm{O}_{12}$ is known, but not fully understood yet. In recent studies, the $\alpha$-polymorph has been identified as thermodynamically 


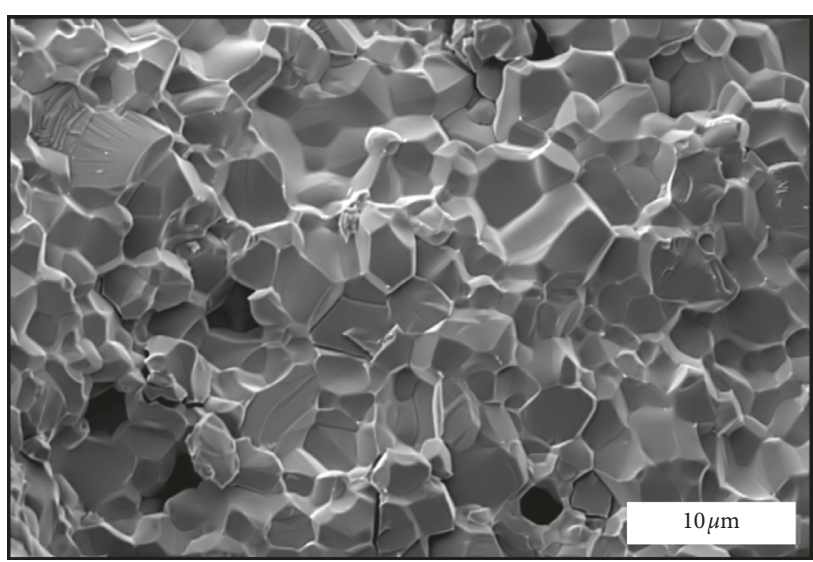

(a)

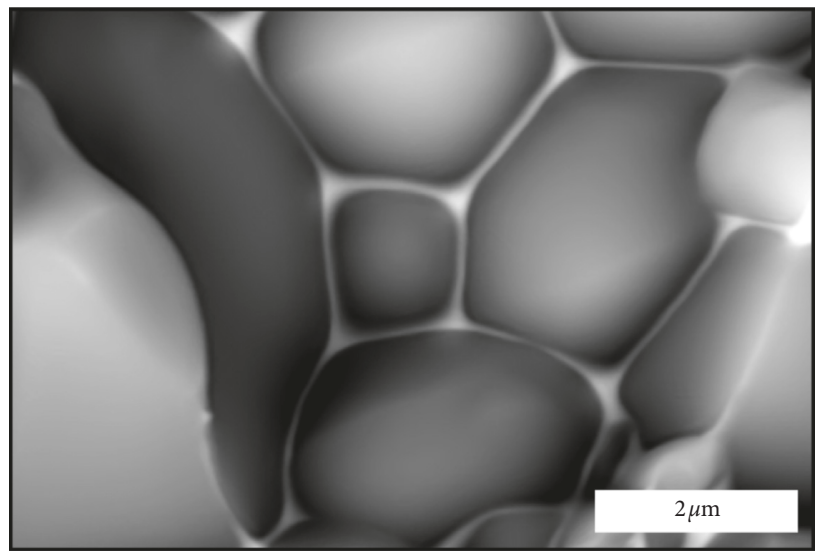

(c)

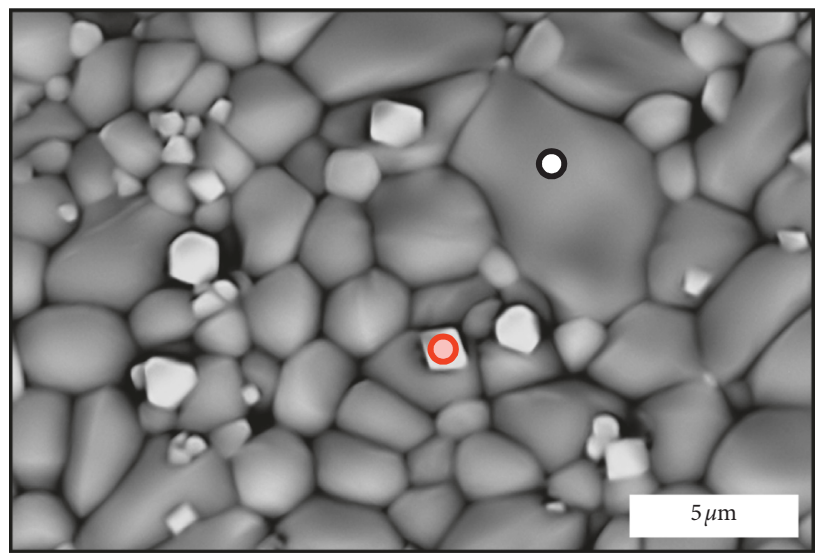

(e)

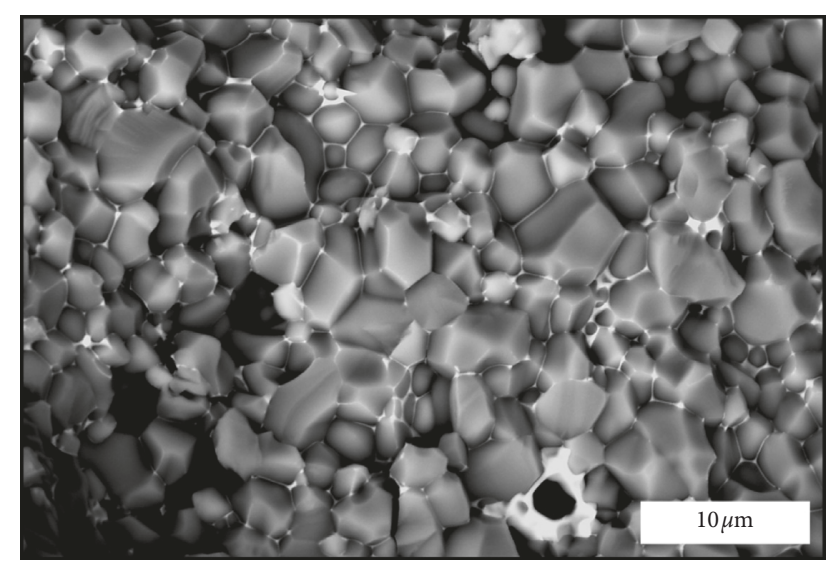

(b)

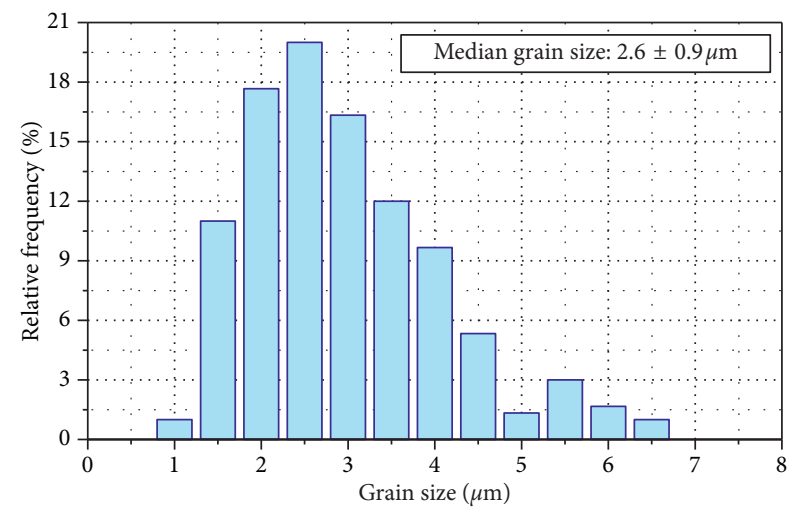

(d)

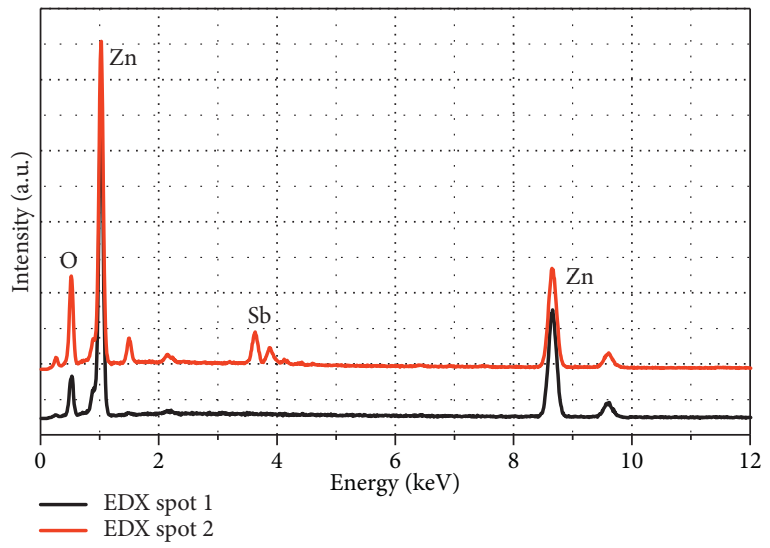

(f)

FIgURE 2: SEM micrographs of the strut fracture surface in zinc oxide ceramic foams: (a) SE image, (b, c) BSE images revealing the Bicontaining secondary phase in the grain boundaries, (d) grain size distribution in the ZnO strut material, and (e, f) BSE micrograph and EDS spectra of the strut surface (black $O$ ) and of individual grains of a Sb-containing secondary phase (red $O$ ).

stable phase above $1225^{\circ} \mathrm{C}$, which, nevertheless, is formed preferentially as metastable phase below $900^{\circ} \mathrm{C}[27,30]$. In the temperature range between $900^{\circ} \mathrm{C}$ and $1225^{\circ} \mathrm{C}$, $\alpha-\mathrm{Zn}_{7} \mathrm{Sb}_{2} \mathrm{O}_{12}$ transforms into the orthorhombic $\beta$-polymorph. Consequently, the formation of $\beta-\mathrm{Zn}_{7} \mathrm{Sb}_{2} \mathrm{O}_{12}$ is expected for the $\mathrm{ZnO}$ foams sintered at $1100^{\circ} \mathrm{C}$.

However, the temperature at which this phase transformation occurs can be drastically affected by doping of
$\alpha-\mathrm{Zn}_{7} \mathrm{Sb}_{2} \mathrm{O}_{12}$ with di- and trivalent metal ions like $\mathrm{Cr}^{3+}$, $\mathrm{Co}^{2+}$, or $\mathrm{Ni}^{2+}$, whereas $\mathrm{Cr}^{3+}$ is most effective [31]. Complete suppression of the orthorhombic $\beta$-phase is found for $\alpha-\mathrm{Zn}_{7} \mathrm{Sb}_{2} \mathrm{O}_{12}$ doped with at least $3.3 \mathrm{~mol} \% \mathrm{Cr}^{3+}$ according to the formula $\mathrm{Zn}_{6.8} \mathrm{Sb}_{1.9} \mathrm{Cr}_{0.3} \mathrm{O}_{12}$. Consequently, the $\alpha$-polymorph with spinel structure is stabilized at room temperature by this doping effect. In the case of doping with trivalent metal ions, an unity of $1 / 3 \mathrm{Sb}^{5+}$ and $2 / 3 \mathrm{Zn}^{2+}$ in 


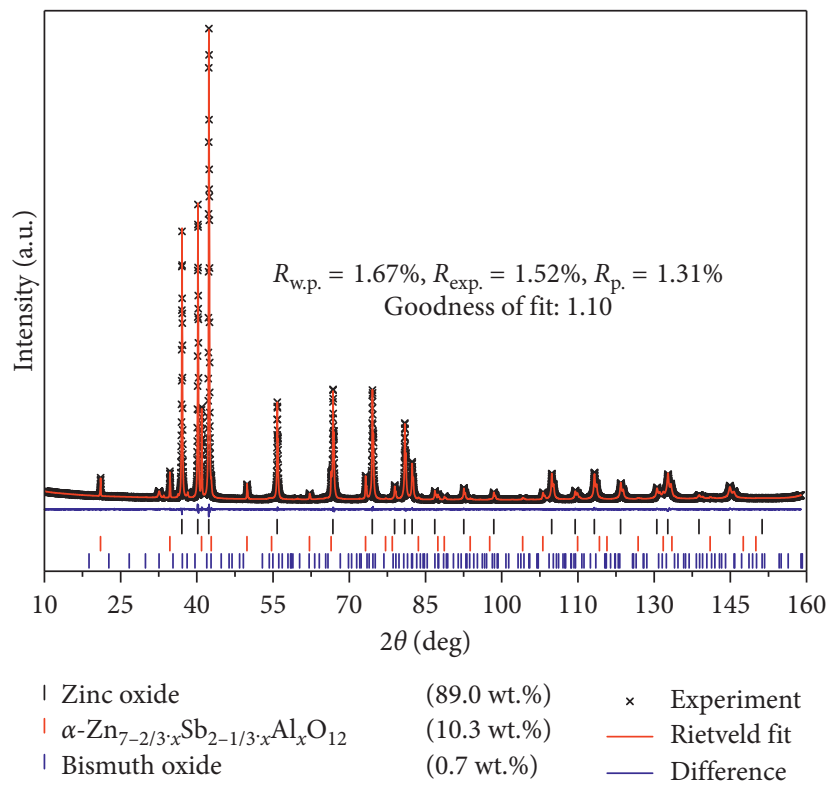

FIGURE 3: Powder XRD pattern of the $\mathrm{ZnO}$ strut material and the corresponding Rietveld fit revealing the individual phase contents of hexagonal $\mathrm{ZnO}$, cubic $\alpha-\mathrm{Zn}_{7} \mathrm{Sb}_{2} \mathrm{O}_{12}$, and tetragonal $\beta-\mathrm{Bi}_{2} \mathrm{O}_{3}$. Deposition numbers of the crystal structure data used for the Rietveld analysis (Crystallography Open Database, COD/Inorganic Structural Database, ICSD): ZnO: COD-9004178, $\alpha-\mathrm{Zn}_{7} \mathrm{Sb}_{2} \mathrm{O}_{12}$ : COD-1007077, and $\beta-\mathrm{Bi}_{2} \mathrm{O}_{3}$ : ICSD-41764.

TABLE 1: Phase and elemental composition of open-celled zinc oxide ceramic foams determined by powder XRD with Rietveld analysis and a comparative EDS measurement.

\begin{tabular}{|c|c|c|c|c|c|}
\hline $\begin{array}{l}\text { Phase composition (Ri } \\
\text { Phase (wt.\%) } \\
\text { ZnO } 20 \text { ppi }\end{array}$ & $\begin{array}{c}\mathrm{ZnO} \\
89.0 \pm 0.14\end{array}$ & $\begin{array}{c}\alpha-\mathrm{Zn}_{7} \mathrm{Sb}_{2} \mathrm{O}_{12} \\
10.3 \pm 0.04\end{array}$ & $\begin{array}{c}\beta-\mathrm{Bi}_{2} \mathrm{O}_{3} \\
0.7 \pm 0.01\end{array}$ & & \\
\hline \multicolumn{6}{|c|}{ Elemental composition (calculated from Rietveld results) } \\
\hline Element (wt.\% \| at.\%) & $\mathrm{Zn}$ & $\mathrm{O}$ & $\mathrm{Sb}$ & $\mathrm{Bi}$ & $\mathrm{Al}$ \\
\hline $\mathrm{ZnO} 20 \mathrm{ppi}$ & $76.6 \| 47.6$ & $20.0 \| 50.8$ & $2.4 \| 0.8$ & $0.6 \| 0.1$ & $0.4 \| 0.7$ \\
\hline Starting powder & $75.4 \| 48.2$ & 19.3|| 50.3 & $2.8 \| 1.0$ & $2.5 \| 0.5$ & $-1-$ \\
\hline \multicolumn{6}{|c|}{ Elemental composition (EDS measurement) } \\
\hline $\mathrm{ZnO} 20$ ppi & $78.1 \| 52.2$ & $16.5 \| 45.0$ & $2.9 \| 1.1$ & $1.7 \| 0.4$ & $0.8 \| 1.3$ \\
\hline
\end{tabular}

${ }^{\#}$ Calculated for the initial powder mixture of $93.9 \mathrm{wt} . \% \mathrm{ZnO}, 3.4 \mathrm{wt} . \% \mathrm{Sb}_{2} \mathrm{O}_{3}$, and $2.7 \mathrm{wt} . \% \mathrm{Bi}_{2} \mathrm{O}_{3}$.

$\alpha-\mathrm{Zn}_{7} \mathrm{Sb}_{2} \mathrm{O}_{12}$ is substituted by one $\mathrm{M}^{3+}$ cation; a spinel phase with a general composition of $\mathrm{Zn}_{7-2 / 3 x} \mathrm{Sb}_{2-1 / 3 x} \mathrm{M}_{x} \mathrm{O}_{12}$ is formed. The end member of this homologous series with $x=6$ is the $\mathrm{Zn}_{3} \mathrm{M}_{6} \mathrm{O}_{12}\left(=\mathrm{ZnM}_{2} \mathrm{O}_{4}\right)$ spinel [32].

In the case of the $\mathrm{ZnO}$ ceramic foams, a possible impurity is $\mathrm{Al}^{3+}$ originating from alumina abrasions during the ballmilling procedure of the initial $\mathrm{ZnO}-\mathrm{Sb}_{2} \mathrm{O}_{3}-\mathrm{Bi}_{2} \mathrm{O}_{3}$ powder mixture. As the $\mathrm{Al}^{3+}$ and $\mathrm{Cr}^{3+}$ ions are similar in size and preferred coordination environment, a similar stabilization mechanism as described for the doping with $\mathrm{Cr}^{3+}$ may be expected. An indication for this hypothesis can be found in the lattice constant of $\alpha-\mathrm{Zn}_{7} \mathrm{Sb}_{2} \mathrm{O}_{12}$ which is $848.7 \mathrm{pm}$ for the spinel secondary phase in the $\mathrm{ZnO}$ strut material and therefore, $11 \mathrm{pm}$ smaller compared to the literature values for the chemically pure $\alpha-\mathrm{Zn}_{7} \mathrm{Sb}_{2} \mathrm{O}_{12}$ phase $[27,33]$. The lattice parameter of $848.7 \mathrm{pm}$, as measured, is very similar to the value of $846.4 \mathrm{pm}$ reported for a spinel with the composition $\mathrm{Zn}_{6} \mathrm{Sb}_{1.5} \mathrm{Al}_{1.5} \mathrm{O}_{12}$ [32]. By applying Vegard's law to the crystallographic data for pure $\alpha-\mathrm{Zn}_{7} \mathrm{Sb}_{2} \mathrm{O}_{12}\left(a_{0}=859.4 \mathrm{pm}\right)$ [33], $\mathrm{Zn}_{6} \mathrm{Sb}_{1.5} \mathrm{Al}_{1.5} \mathrm{O}_{12}\left(a_{0}=846.4 \mathrm{pm}\right)$ [32], and the end member of the homologous series, $\mathrm{ZnAl}_{2} \mathrm{O}_{4}\left(=\mathrm{Zn}_{3} \mathrm{Al}_{6} \mathrm{O}_{12}\right.$; $a_{0}=809.1 \mathrm{pm}$ ), [34], an aluminum content of $x=1.25$ was approximated (Figure 4) [35]. This corresponds to the composition $\mathrm{Zn}_{6.17} \mathrm{Sb}_{1.58} \mathrm{Al}_{1.25} \mathrm{O}_{12}$ for the spinel secondary phase in the $\mathrm{ZnO}$ strut material. Consideration of this $\mathrm{Al}^{3+}$ doping results in a significantly improved fit of the $\alpha-\mathrm{Zn}_{7} \mathrm{Sb}_{2} \mathrm{O}_{12}$ reflections in the Rietveld analysis of the diffraction data (Figure 3).

The $\mathrm{Bi}_{2} \mathrm{O}_{3}$ amount of 0.7 wt.\%, corresponding to 0.1 at.\% $\mathrm{Bi}$ (Table 1), in the $\mathrm{ZnO}$ strut material as detected by XRD and Rietveld analysis was significantly lower than in the initial powder mixture (2.7 wt. $\% \mathrm{Bi}_{2} \mathrm{O}_{3} / 0.5$ at. $\% \mathrm{Bi}$ ). This is an indication for the presence of an amorphous $\mathrm{Bi}$ containing secondary phase, most likely formed during the liquid phase sintering process at the $\mathrm{ZnO}$ grain boundaries (Figure 2(c)) $[25,26]$. As this amorphous phase is hidden for XRD and Rietveld analysis, an underestimation of the total Bi content is the result. Accordingly, a Bi content of 0.4 at.\% was detected by EDS spectroscopy, which takes the amorphous material into account and is in good 


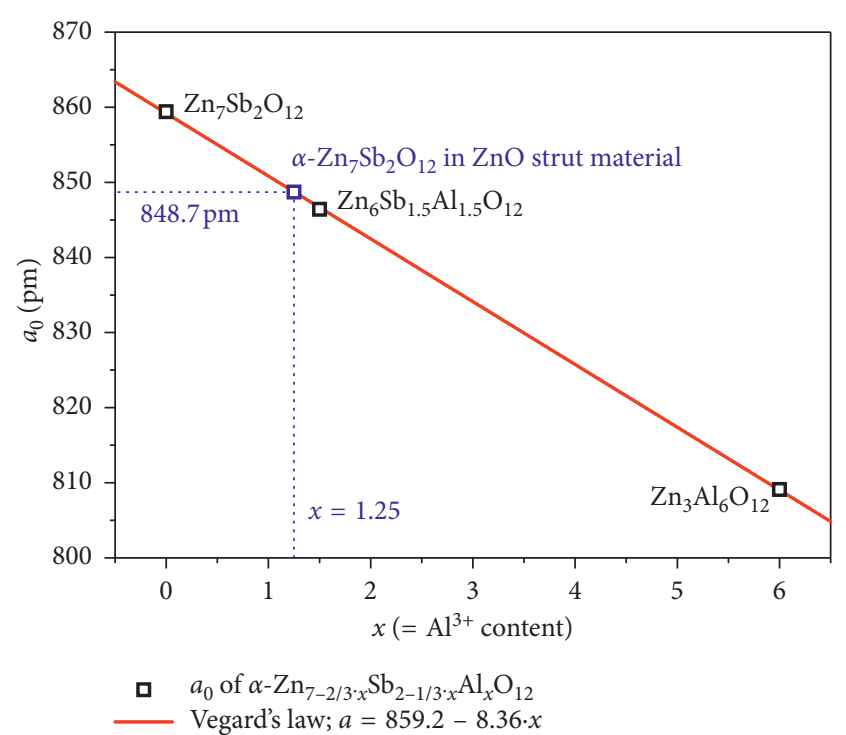

Figure 4: Approximation of the $\mathrm{Al}^{3+}$ content in the cubic $\mathrm{Zn}_{7-2 /}$ ${ }_{3 x} \mathrm{Sb}_{2-1 / 3 x} \mathrm{Al}_{x} \mathrm{O}_{12}$ secondary phase in the $\mathrm{ZnO}$ strut material by applying Vegard's law on published crystallographic data of the pure spinels $\alpha-\mathrm{Zn}_{7} \mathrm{Sb}_{2} \mathrm{O}_{12}$ and $\mathrm{ZnAl}_{2} \mathrm{O}_{4}\left(=\mathrm{Zn}_{3} \mathrm{Al}_{6} \mathrm{O}_{12}\right)$ as well as an $\mathrm{Al}$-doped spinel with the composition $\mathrm{Zn}_{3} \mathrm{Sb}_{1.5} \mathrm{Al}_{1.5} \mathrm{O}_{12}$.

agreement with the $\mathrm{Bi}$ amount in the initial powder mixture (Table 1). In addition, no indication for the partial loss of the sintering aid $\mathrm{Sb}_{2} \mathrm{O}_{3}$ by formation of volatile, molecular compounds like $\mathrm{Sb}_{4} \mathrm{O}_{6}$ was found [26]. The Sb content in the $\mathrm{ZnO}$ strut material measured by XRD and EDS analysis was 0.8 at.\% and 1.1 at.\%, respectively, and in good agreement to the $\mathrm{Sb}$ amount of 1.0 at.\% in the initial $\mathrm{ZnO}-\mathrm{Sb}_{2} \mathrm{O}_{3}-\mathrm{Bi}_{2} \mathrm{O}_{3}$ powder mixture. Furthermore, an aluminum concentration of 1.3 at.\% was detected by EDS spectroscopy (Figure 5), which is in the same order of magnitude than the $\mathrm{Al}$ amount calculated from the results of the Rietveld analysis (0.7 at.\%) and gives further evidence of the $\mathrm{Al}^{3+}$ doping of $\alpha-\mathrm{Zn}_{7} \mathrm{Sb}_{2} \mathrm{O}_{12}$. Nevertheless, it has to be noted that the accuracy of the EDS analyses for the trace elements ( $\mathrm{Sb}, \mathrm{Bi}, \mathrm{Al}$ ) is limited and a relative error of $4 \%$ to $12 \%$ has to be considered.

3.2. Macrostructure of $\mathrm{ZnO}$ Ceramic Foams. The total porosity of the obtained $\mathrm{ZnO}$ ceramic foams is high with a value of $93.6 \pm 0.4 \%$ (Table 2). According to the Archimedes measurements and in conformity with the microstructure observed in the SEM investigations, virtually no residual porosity is present in the $\mathrm{ZnO}$ strut material $(<0.5 \%$ w. r. $\mathrm{t}$. the strut volume). Only the hollow strut cavities originating from the PU template are present; they contribute a porosity of $32 \pm 3 \%$ w. r. t. the total strut volume. This value is in good agreement to alumina foams with a densely sintered strut material made from the same PU templates [36].

An isotropic linear shrinkage of $16 \pm 1 \%$, equivalent to a volumetric shrinkage of $41 \pm 4 \%$ in relation to the initial foam template dimensions, has been observed during the sintering process at $1100^{\circ} \mathrm{C}$. This is in a good agreement to sintering studies of dense ceramics in the $\mathrm{ZnO}-\mathrm{Sb}_{2} \mathrm{O}_{3^{-}}$

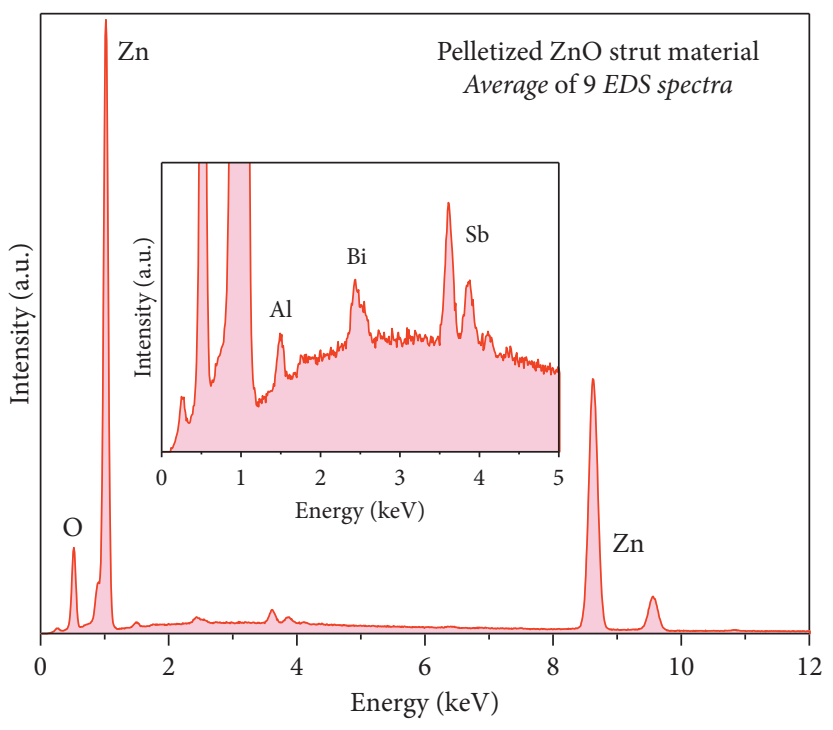

FIgURE 5: EDS analysis averaged from 9 separate EDS spectra recorded on an uniaxially pressed slab of the $\mathrm{ZnO}$ strut material. Inset: Signals of the trace elements $\mathrm{Al}, \mathrm{Bi}$, and $\mathrm{Sb}$.

Table 2: Properties of open-celled zinc oxide ceramic foams. The total porosity and cell porosity values refer to the geometric foam volume and the ratio $V_{\text {pores }} / V_{\text {foam }}$. The strut porosity is based on the strut volume and the ratio $V_{\text {strut pores }} / V_{\text {struts }}$ as determined by the water immersion technique.

\begin{tabular}{lcc}
\hline & & ZnO, 20 ppi \\
\hline Foam porosity & Total & $93.6 \pm 0.4 \%$ \\
$\left(V_{\text {pores }} / V_{\text {foam }}\right)$ & Cell $^{\mathrm{a}}$ & $93.5 \pm 0.9 \%$ \\
Strut porosity & Total $^{\mathrm{b}}$ & $32 \pm 5 \%$ \\
$\left(V_{\text {strut pores }} / V_{\text {strut }}\right)$ & Hollow strut $^{\mathrm{b}}$ & $32 \pm 3 \%$ \\
Shrinkage & Strut material $^{\mathrm{c}}$ & $<0.5 \%$ \\
& Linear $^{\text {Morphology }(\mathrm{CT})}$ & $15.8 \pm 1.1 \%$ \\
& Volumetric $^{\text {Strut thickness }}$ & $41 \pm 4 \%$ \\
Thermal conductivity & Cell size & $0.38 \pm 0.15 \mathrm{~mm}$ \\
& Foam & $2.69 \pm 0.23 \mathrm{~mm}$ \\
Compressive strength & Bulk material & $\mathrm{d}$ \\
& Average strength & $37 \mathrm{~W} \cdot \mathrm{m}^{-1} \cdot \mathrm{K}^{-1}$ \\
& Weibull modulus & $0.15 \pm 0.03 \mathrm{MPa}$ \\
\hline
\end{tabular}

${ }^{\mathrm{a}}$ Including the cavities resulting from the PU template burnout. ${ }^{\mathrm{b}}$ Related to the overall strut volume; $V_{\text {hollow strut }}\left(V_{\text {hollow strut }}+V_{\text {strut material pores }}+V_{\text {solid }}\right)$ and $V_{\text {strut material pores }} /\left(V_{\text {hollow strut }}+V_{\text {strut material pores }}+V_{\text {solid }}\right) .{ }^{c}$ Related to the volume of the strut material excluding the cavities resulting from the PU template burnout; $V_{\text {strut material pores }} /\left(V_{\text {strut material pores }}+V_{\text {solid }}\right) .{ }^{\mathrm{d}}$ Extrapolated thermal conductivity of the bulk strut material according to Ashby's model [43].

$\mathrm{Bi}_{2} \mathrm{O}_{3}$ system, for which a linear shrinkage of $17 \%$ is reported for the same powder composition as used within this work [11].

The open porous structure of the $\mathrm{ZnO}$ ceramic foams is confirmed by computed tomography; a total porosity of $94 \%$ and a closed porosity $<0.1 \%$ have been determined, which is in good agreement to the results of the Archimedes measurements. In addition, no significant pore window blocking is present resulting in a thoroughly open-cellular structure (Figure 6(b)). The cell size in the $\mathrm{ZnO}$ ceramic foams ranges 


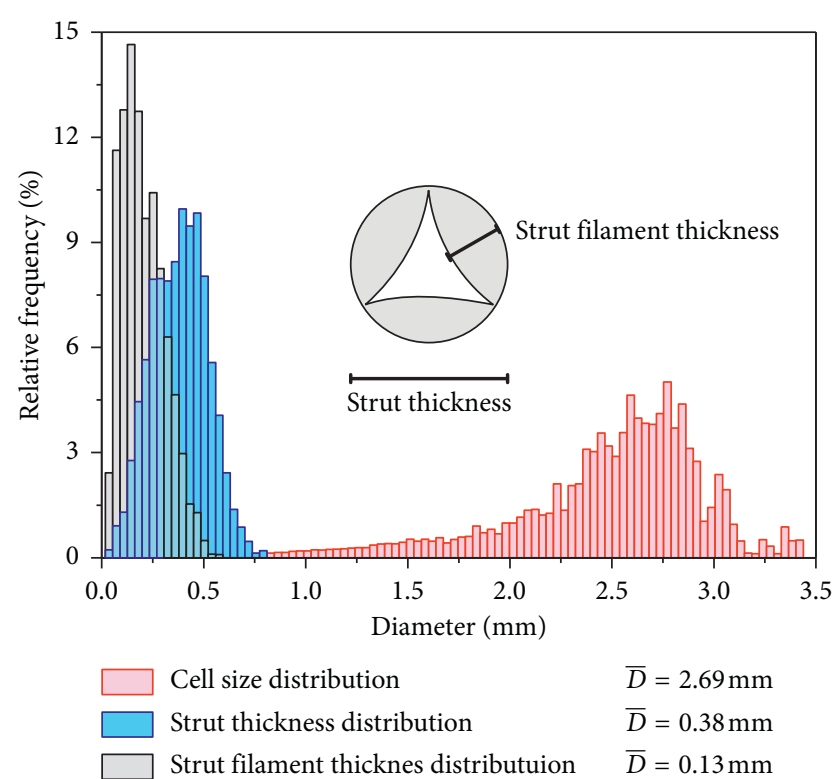

(a)

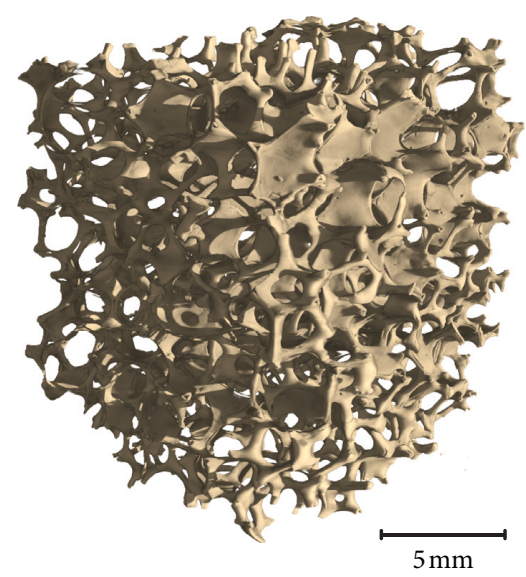

(b)

FIGURE 6: (a) Strut thickness and cell size distributions calculated from a three-dimensional $\mu$-CT reconstruction of a 20 ppi $\mathrm{ZnO}$ ceramic foam; (b) three-dimensional reconstruction of the same $\mathrm{ZnO}$ foam.

between $1.8 \mathrm{~mm}$ and $3.2 \mathrm{~mm}$ with an average of $2.7 \pm 0.2 \mathrm{~mm}$ according to a morphometric analysis of the threedimensional reconstruction volume (Table 2, Figure 6(a)). The strut thickness and strut filament thickness amount to $0.38 \pm 0.15 \mathrm{~mm}$ and $0.13 \pm 0.08 \mathrm{~mm}$ on average. As expected, the morphological parameters of the $\mathrm{ZnO}$ ceramic foams are within the same range as previously reported for alumina cellular ceramics made from the same 20 ppi PU foam templates [21].

3.3. Mechanical and Thermal Properties of $\mathrm{ZnO}$ Ceramic Foams. The compressive strength data obtained on all 35 $\mathrm{ZnO}$ foam specimens could be satisfactorily modelled by a two-parameter Weibull distribution [18]. An average compressive strength $\sigma_{\mathrm{fc}}$ of $0.15 \pm 0.03 \mathrm{MPa}$ and a Weibull modulus $m$ of 5.6 were calculated (Figure 7 ). The modulus

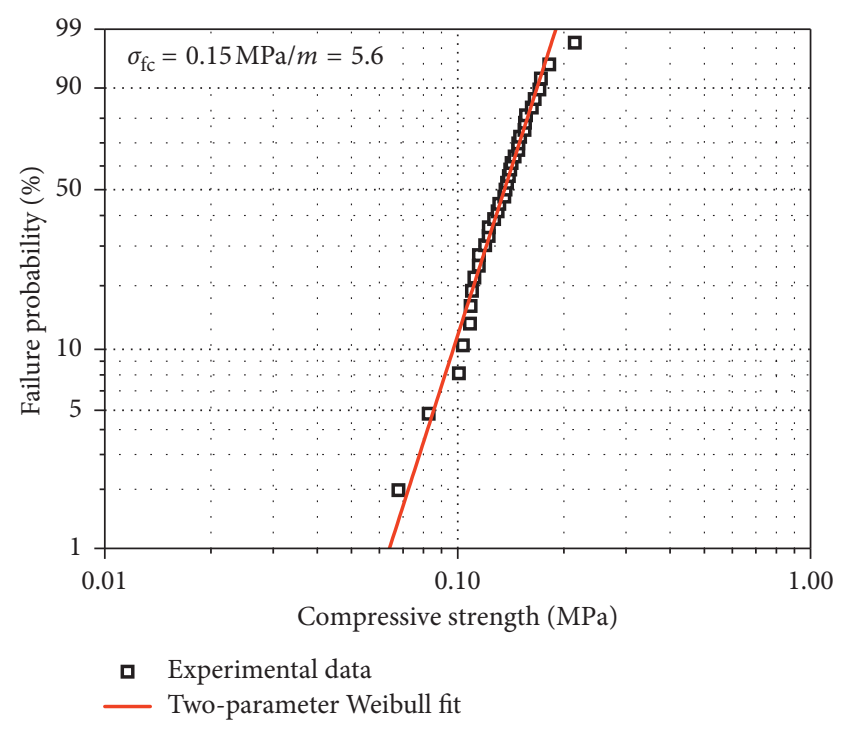

FIgURE 7: Compressive strength data of 20 ppi $\mathrm{ZnO}$ ceramic foams $(\square)$ and the corresponding fit with the two-parameter Weibull function (red line).

$m$ is in the expected range for brittle cellular ceramic structures [37, 38]. Essentially, the low compressive strength is a consequence of the high porosity of $93.6 \%$ in the $\mathrm{ZnO}$ ceramic foams; accordingly, the $\sigma_{\mathrm{fc}}$ value is in the same order of magnitude as the compressive strength of cellular alumina with a similar microstructure and porosity range $\left(\sigma_{\mathrm{fc}}=0.19 \mathrm{MPa} / 0.34 \mathrm{MPa}\right.$ at $94.0 \% / 93 \%$ total porosity) [37].

For the evaluation of the strength-porosity correlation, the compressive strength data obtained for the cellular $\mathrm{ZnO}$ specimens were modelled with the Gibson-Ashby (GA) relation for the description of the crushing behavior of brittle, cellular materials (equation (1)) [39]:

$$
\sigma_{\mathrm{fc}}=C_{6} \cdot\left(\rho_{\mathrm{rel}}\right)^{n} \cdot \sigma_{\mathrm{fs}} .
$$

According to equation (1), the compressive strength $\sigma_{\mathrm{fc}}$ of a brittle, cellular sample is a function of its relative density and the bending strength $\sigma_{\mathrm{fs}}$ of the bulk strut material. The density exponent $n$ describes the effect of the porosity on the mechanical strength; for open-celled foams, a value of 1.5 is commonly used. The constant $C_{6}$ is related to the cellular geometry of the foam; for cellular ceramics made by the polymer sponge replication, usually a value of 0.16 is applied for $C_{6}$ [40]. The strength-porosity correlation for the $\mathrm{ZnO}$ ceramic foams is shown in Figure 8; the bending strength $\sigma_{\mathrm{fs}}$ was varied to fit the Gibson-Ashby model to the compressive strength data of the $\mathrm{ZnO}$ foams. An adequate GA fit is the result, and a bending strength of $54 \pm 2 \mathrm{MPa}$ is approximated for the bulk $\mathrm{ZnO}$ strut material. This is in the same order of magnitude than the bending strength of compact zinc oxide varistor ceramics, which ranges between $80 \mathrm{MPa}$ and $120 \mathrm{MPa}[41,42]$.

The thermal conductivity of the obtained $\mathrm{ZnO}$ ceramic foams determined by the transient plane source technique was $0.82 \pm 0.07 \mathrm{~W} \cdot \mathrm{m}^{-1} \cdot \mathrm{K}^{-1}$ at $93.6 \%$ total porosity. In order to evaluate the thermal properties of the $\mathrm{ZnO}$ strut 


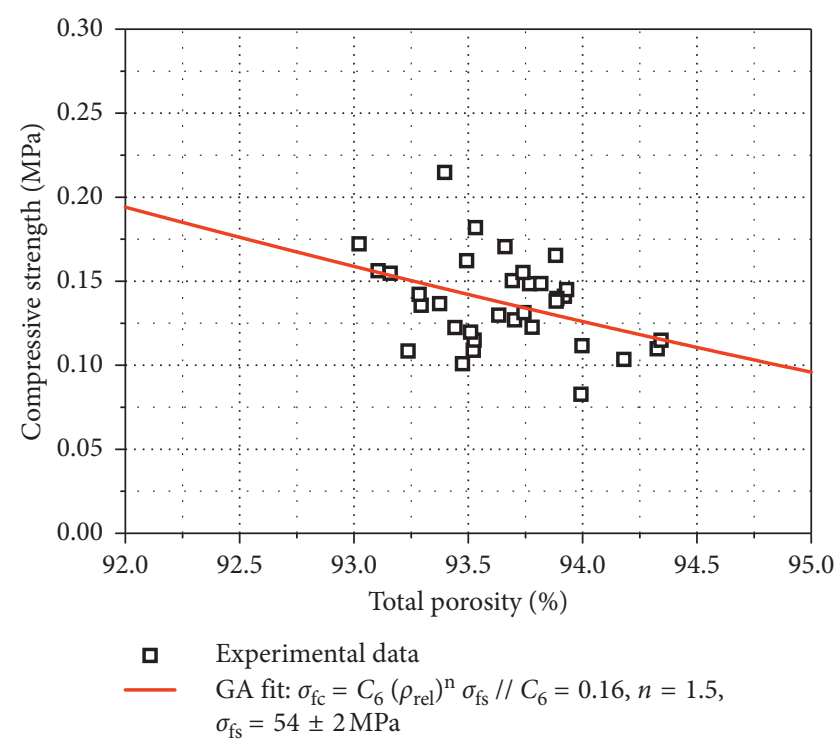

Figure 8: Compressive strength data of 20 ppi $\mathrm{ZnO}$ foams ( $\square$ ) and the corresponding fit with the Gibson-Ashby model for the strength-porosity correlation (red line).

material, the bulk thermal conductivity $\lambda_{\mathrm{b}}$ has been approximated. As the strut material contains virtually no microstructural porosity, a simple model derived by Ashby based on the rule of mixture was applied (equation (2)) [43]:

$$
\lambda_{\mathrm{b}}=\frac{\lambda_{\mathrm{f}}-P_{\text {cell }} \cdot \lambda_{\mathrm{g}}}{(1 / 3) \cdot\left(1-P_{\text {cell }}\right)} .
$$

The parameter $\lambda_{\mathrm{g}}$ is the thermal conductivity of the gas phase (air; $\lambda_{\mathrm{g}}=0.0264 \mathrm{~W} \cdot \mathrm{m}^{-1} \cdot \mathrm{K}^{-1}$ ), [44] $\lambda_{\mathrm{f}}$ is the thermal conductivity of the foam and $P_{\text {cell }}$ is the cell porosity of the $\mathrm{ZnO}$ foams including the hollow strut cavities $\left(P_{\text {cell }}=93.5 \%\right)$ [36]. The calculated bulk thermal conductivity of the $\mathrm{ZnO}$ strut material is $37 \mathrm{~W} \cdot \mathrm{m}^{-1} \cdot \mathrm{K}^{-1}$, which is slightly lower compared to experimental and theoretical values reported for chemically pure $\mathrm{ZnO}\left(\approx 50 \mathrm{~W} \cdot \mathrm{m}^{-1} \cdot \mathrm{K}^{-1}\right)[7,45]$. The reduced thermal conductivity of the $\mathrm{ZnO}$ strut material can be explained by the presence of the $\mathrm{Bi}_{2} \mathrm{O}_{3}$ and $\alpha-\mathrm{Zn}_{7} \mathrm{Sb}_{2} \mathrm{O}_{12}$ secondary phases, which have a very low thermal conductivity of $1.1 \mathrm{~W} \cdot \mathrm{m}^{-1} \cdot \mathrm{K}^{-1}$ and $2.3 \mathrm{~W} \cdot \mathrm{m}^{-1} \cdot \mathrm{K}^{-1}$, respectively [46]. The thermal conductivity of $37 \mathrm{~W} \cdot \mathrm{m}^{-1} \cdot \mathrm{K}^{-1}$ of the bulk $\mathrm{ZnO}$ strut material is in good agreement with the value of $43 \mathrm{~W} \cdot \mathrm{m}^{-1} \cdot \mathrm{K}^{-1}$ extrapolated by Landauer's theory of effective percolation for a mixture of $90.2 \mathrm{vol} . \% \mathrm{ZnO}$ and $9.8 \mathrm{vol} \%$ $\alpha-\mathrm{Zn}_{7} \mathrm{Sb}_{2} \mathrm{O}_{12}$ [47]. Consequently, for commercial $\mathrm{ZnO}$ based varistor ceramics containing the same $\mathrm{Sb}_{2} \mathrm{O}_{3}$ and $\mathrm{Bi}_{2} \mathrm{O}_{3}$ sintering additives, a reduced thermal conductivity in the range between $20 \mathrm{~W} \cdot \mathrm{m}^{-1} \cdot \mathrm{K}^{-1}$ and $35 \mathrm{~W} \cdot \mathrm{m}^{-1} \cdot \mathrm{K}^{-1}$ is found as well [46].

\section{Conclusions}

The manufacturing of cellular $\mathrm{ZnO}$ ceramic foams with the established polymer sponge replication technique and an aqueous $\mathrm{ZnO}$ dispersion and $\mathrm{Sb}_{2} \mathrm{O}_{3}$ and $\mathrm{Bi}_{2} \mathrm{O}_{3}$ as sintering additives has been demonstrated. The obtained open-celled $\mathrm{ZnO}$ foams show a high total porosity of $93.6 \%$ including the characteristic hollow strut cavities typical for this processing technique. The strut material itself is almost fully densified; its microstructure consists of $\mathrm{ZnO}$ grains with an amorphous Bi-containing grain boundary phase. In addition, an Al-doped spinel secondary phase with the composition $\mathrm{Zn}_{6.17} \mathrm{Sb}_{1.58} \mathrm{Al}_{1.25} \mathrm{O}_{12}$ was formed. The dopant $\mathrm{Al}^{3+}$ originates from a contamination during the ball-milling process of the raw powders and leads to a stabilization of the thermodynamically metastable spinel phase at room temperature.

The mechanical and thermal properties of the obtained $\mathrm{ZnO}$ ceramic foams were evaluated, and an average compressive strength of $0.15 \mathrm{MPa}$ and a thermal conductivity of $0.82 \mathrm{~W} \cdot \mathrm{m}^{-1} \cdot \mathrm{K}^{-1}$ were measured. The strength-porosity correlation was modelled with the Gibson-Ashby law for brittle, cellular structures; a bending strength of $54 \mathrm{MPa}$ for the bulk $\mathrm{ZnO}$ strut material being in good accord to published data on comparable $\mathrm{ZnO}$-based varistor ceramics was estimated. From the thermal conductivity data, a bulk thermal conductivity of $37 \mathrm{~W} \cdot \mathrm{m}^{-1} \cdot \mathrm{K}^{-1}$ was determined for the $\mathrm{ZnO}$ strut material, which is in good agreement with the thermal conductivity of $\mathrm{ZnO}$ varistor ceramics of similar composition.

\section{Data Availability}

The data used to support the findings of this study are included within the article.

\section{Conflicts of Interest}

The authors declare that they have no conflicts of interest.

\section{Acknowledgments}

Funding for this research was supplied by the federal state of Saxony-Anhalt.

\section{References}

[1] M. V. Twigg and J. T. Richardson, "Fundamentals and applications of structured ceramic foam catalysts," Industrial and Engineering Chemistry Research, vol. 46, no. 12, pp. 4166-4177, 2007.

[2] K. Schwartzwalder, H. Somers, and A. V. Somers, "Method of making porous ceramic articles," US 3,090,094, 21.02.1961.

[3] A. R. Studart, U. T. Gonzenbach, E. Tervoort, and L. J. Gauckler, "Processing routes to macroporous ceramics: a review," Journal of the American Ceramic Society, vol. 89, no. 6, pp. 1771-1789, 2006.

[4] T. Fey, U. Betke, S. Rannabauer, and M. Scheffler, "Reticulated replica ceramic foams: processing, functionalization, and characterization," Advanced Engineering Materials, vol. 19, no. 10, article 1700369, 2017.

[5] B. Pamplin, "The adamantine family of compounds," Progress in Crystal Growth and Characterization, vol. 3, no. 2-3, pp. 179-192, 1980.

[6] G. A. Slack, "Nonmetallic crystals with high thermal conductivity," Journal of Physics and Chemistry of Solids, vol. 34, no. 2, pp. 321-335, 1973. 
[7] M. W. Wolf and J. J. Martin, "Low temperature thermal conductivity of zinc oxide," Physica Status Solidi (a), vol. 17, no. 1, pp. 215-220, 1973.

[8] Ü. Özgür, Y. I. Alivov, C. Liu et al., “A comprehensive review of $\mathrm{ZnO}$ materials and devices," Journal of Applied Physics, vol. 98, no. 4, p. 041301, 2005.

[9] M. Inada, "Crystal phases of nonohmic zinc oxide ceramics," Japanese Journal of Applied Physics, vol. 17, no. 1, pp. 1-10, 1978.

[10] M. Inada, "Formation mechanism of nonohmic zinc oxide ceramics," Japanese Journal of Applied Physics, vol. 19, no. 3, pp. 409-419, 1980.

[11] J. Kim, T. Kimura, and T. Yamaguchi, "Sintering of zinc oxide doped with antimony oxide and bismuth oxide," Journal of the American Ceramic Society, vol. 72, no. 8, pp. 1390-1395, 1989.

[12] E. R. Leite, M. A. L. Nobre, E. Longo, and J. A. Varela, "Microstructural development of $\mathrm{ZnO}$ varistor during reactive liquid phase sintering," Journal of Materials Science, vol. 31, no. 20, pp. 5391-5398, 1996.

[13] DIN EN 623-2:1993-11, Hochleistungskeramik; Monolithische Keramik; Allgemeine und strukturelle Eigenschaften; Teil 2: Bestimmung von Dichte und Porosität, Beuth Verlag, Berlin, Germany, 1993.

[14] H. M. Rietveld, "A profile refinement method for nuclear and magnetic structures," Journal of Applied Crystallography, vol. 2, no. 2, pp. 65-71, 1969.

[15] A. A. Coelho, Topas Academic V5, Coelho Software, Brisbane, Australia, 2012.

[16] T. Log and S. E. Gustafsson, "Transient plane source (TPS) technique for measuring thermal transport properties of building materials," Fire and Materials, vol. 19, no. 1, pp. 43-49, 1995.

[17] Y. He, "Rapid thermal conductivity measurement with a hot disk sensor," Thermochimica Acta, vol. 436, no. 1-2, pp. 122-129, 2005.

[18] W. Weibull, "A statistical distribution function of wide applicability," Journal of Applied Mechanics, vol. 20, pp. 293297, 1951.

[19] C. Ronninger, Visual-XSel 14, CRGRAPH, Starnberg, Germany, 2018.

[20] U. Betke, S. Dalicho, S. Rannabauer, A. Lieb, F. Scheffler, and M. Scheffler, "Impact of slurry composition on properties of cellular alumina: a computed tomographic study," Advanced Engineering Materials, vol. 19, no. 10, article 1700138, 2017.

[21] U. Betke, M. Klaus, J. G. Eggebrecht, M. Scheffler, and A. Lieb, "MOFs meet macropores: dynamic direct crystallization of the microporous aluminum isophthalate CAU-10 on reticulated open-cellular alumina foams," Microporous and Mesoporous Materials, vol. 265, pp. 43-56, 2018.

[22] S. Y. Gómez, O. A. Alvarez, J. A. Escobar, J. B. Rodrigues Neto, C. R. Rambo, and D. Hotza, "Relationship between rheological behaviour and final structure ofAl2O3and YSZ foams produced by replica," Advances in Materials Science and Engineering, vol. 2012, Article ID 549508, 9 pages, 2012.

[23] C. Voigt, C. G. Aneziris, J. Hubálková, and G. Franks, "Rheological characterization of slurries for the preparation of alumina foams via replica technique," Journal of the American Ceramic Society, vol. 98, no. 5, pp. 1460-1463, 2015.

[24] S. S. Bhat, U. V. Waghmare, and U. Ramamurty, "Effect of oxygen vacancies on the elastic properties of zinc oxide: a firstprinciples investigation," Computational Materials Science, vol. 99, pp. 133-137, 2015.
[25] J. P. Guha, Š. Kunej, and D. Suvorov, "Phase equilibrium relations in the binary system $\mathrm{Bi} 2 \mathrm{O} 3-\mathrm{ZnO}$," Journal of $\mathrm{Ma}$ terials Science, vol. 39, no. 3, pp. 911-918, 2004.

[26] M. L. Arefin, F. Raether, D. Dolejš, and A. Klimera, "Phase formation during liquid phase sintering of $\mathrm{ZnO}$ ceramics," Ceramics International, vol. 35, no. 8, pp. 3313-3320, 2009.

[27] G. C. Miles and A. R. West, "Polymorphism and thermodynamic stability of Zn7Sb2O12," Journal of the American Ceramic Society, vol. 88, no. 2, pp. 396-398, 2005.

[28] F. Raether and M. L. Arefin, "Kinetic field approach to study liquid phase sintering of $\mathrm{ZnO}$ based ceramics," Ceramics International, vol. 36, no. 4, pp. 1429-1437, 2010.

[29] C.-H. Lu, N. Chyi, H.-W. Wong, and W.-J. Hwang, "Effects of additives and secondary phases on the sintering behavior of zinc oxide-based varistors," Materials Chemistry and Physics, vol. 62, no. 2, pp. 164-168, 2000.

[30] E. Filipek and G. Dąbrowska, "Unknown thermal properties of ZnSb2O6 and Zn7Sb2O12 compounds," Journal of Thermal Analysis and Calorimetry, vol. 94, no. 1, pp. 195-201, 2008.

[31] R. Harrington, G. C. Miles, and A. R. West, "Phase equilibria, crystal chemistry and polymorphism of $\mathrm{Zn}_{7} \mathrm{Sb}_{2} \mathrm{O}_{12}$ doped with $\mathrm{Cr}$ and Ni," Materials Research Bulletin, vol. 43, no. 8-9, pp. 1949-1956, 2008.

[32] P. Tarte and J. Preudhomme, "Studies of spinels. VI. Antimonates MII4MIIISbVO8, a new, large family of spinels presenting order-disorder transitions," Journal of Solid State Chemistry, vol. 29, no. 2, pp. 273-284, 1979.

[33] J. Dulac and A. Durif, "Étude de deux antimoniates spinelles," Comptes Rendus Hebdomadaires des Seances de l'Academie des Sciences, vol. 251, pp. 747-749, 1960.

[34] D. Levy, A. Pavese, A. Sani, and V. Pischedda, "Structure and compressibility of synthetic $\mathrm{ZnAl} 2 \mathrm{O} 4$ (gahnite) under highpressure conditions, from synchrotron X-ray powder diffraction," Physics and Chemistry of Minerals, vol. 28, no. 9, pp. 612-618, 2001.

[35] L. Vegard, "Die konstitution der mischkristalle und die raumfüllung der atome," Zeitschrift für Physik, vol. 5, no. 1, pp. 17-26, 1921.

[36] U. Betke, A. Lieb, F. Scheffler, and M. Scheffler, "Manufacturing of reticulated open-cellular aluminum nitride ceramic foams from aqueous AlN suspensions," Advanced Engineering Materials, vol. 19, no. 3, article 1600660, 2017.

[37] S. Rannabauer, G.-M. Söffker, M. Scheunemann, U. Betke, and M. Scheffler, "Increased mechanical stability and thermal conductivity of alumina reticulated porous ceramics (RPC) by nanoparticle infiltration processing," Advanced Engineering Materials, vol. 19, no. 10, article 1700211, 2017.

[38] P. Colombo, J. R. Hellmann, and D. L. Shelleman, "Mechanical properties of silicon oxycarbide ceramic foams," Journal of the American Ceramic Society, vol. 84, no. 10, pp. 2245-2251, 2001.

[39] M. F. Ashby and R. F. M. Medalist, "The mechanical properties of cellular solids," Metallurgical Transactions A, vol. 14, no. 9, pp. 1755-1769, 1983.

[40] R. Brezny and D. J. Green, "Mechanical behavior of cellular ceramics," in Materials Science and Technology, R. W. Cahn, P. Haasen, and E. J. Kramer, Eds., pp. 463-516, Wiley-VCH Verlag GmbH \& Co. KGaA, Weinheim, Germany, 2006.

[41] B. Balzer, M. Hagemeister, P. Kocher, and L. J. Gauckler, "Mechanical strength and microstructure of zinc oxide varistor ceramics," Journal of the American Ceramic Society, vol. 87, no. 10, pp. 1932-1938, 2004. 
[42] H. N. Yoshimura, A. L. Molisani, N. E. Narita, J. L. A. Manholetti, and J. M. Cavenaghi, "Mechanical properties and microstructure of zinc oxide varistor ceramics," Materials Science Forum, vol. 530-531, pp. 408-413, 2006.

[43] M. F. Ashby, "The properties of foams and lattices," Philosophical Transactions of the Royal Society A: Mathematical, Physical and Engineering Sciences, vol. 364, no. 1838, pp. 15-30, 2006.

[44] E. W. Lemmon and R. T. Jacobsen, "Viscosity and thermal conductivity equations for nitrogen, oxygen, argon, and air," International Journal of Thermophysics, vol. 25, no. 1, pp. 21-69, 2004.

[45] X. Wu, J. Lee, V. Varshney, J. L. Wohlwend, A. K. Roy, and T. Luo, "Thermal conductivity of wurtzite zinc-oxide from first-principles lattice dynamics-a comparative study with gallium nitride," Scientific Reports, vol. 6, no. 1, p. 22504, 2016.

[46] C. M. Barrado, E. R. Leite, P. R. Bueno, E. Longo, and J. A. Varela, "Thermal conductivity features of ZnO-based varistors using the laser-pulse method," Materials Science and Engineering: A, vol. 371, no. 1-2, pp. 377-381, 2004.

[47] R. Landauer, "The electrical resistance of binary metallic mixtures," Journal of Applied Physics, vol. 23, no. 7, pp. 779-784, 1952. 


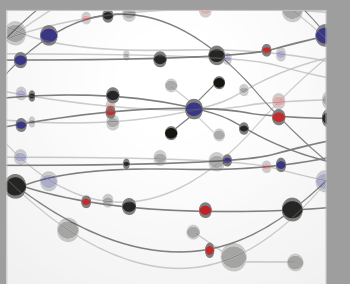

The Scientific World Journal
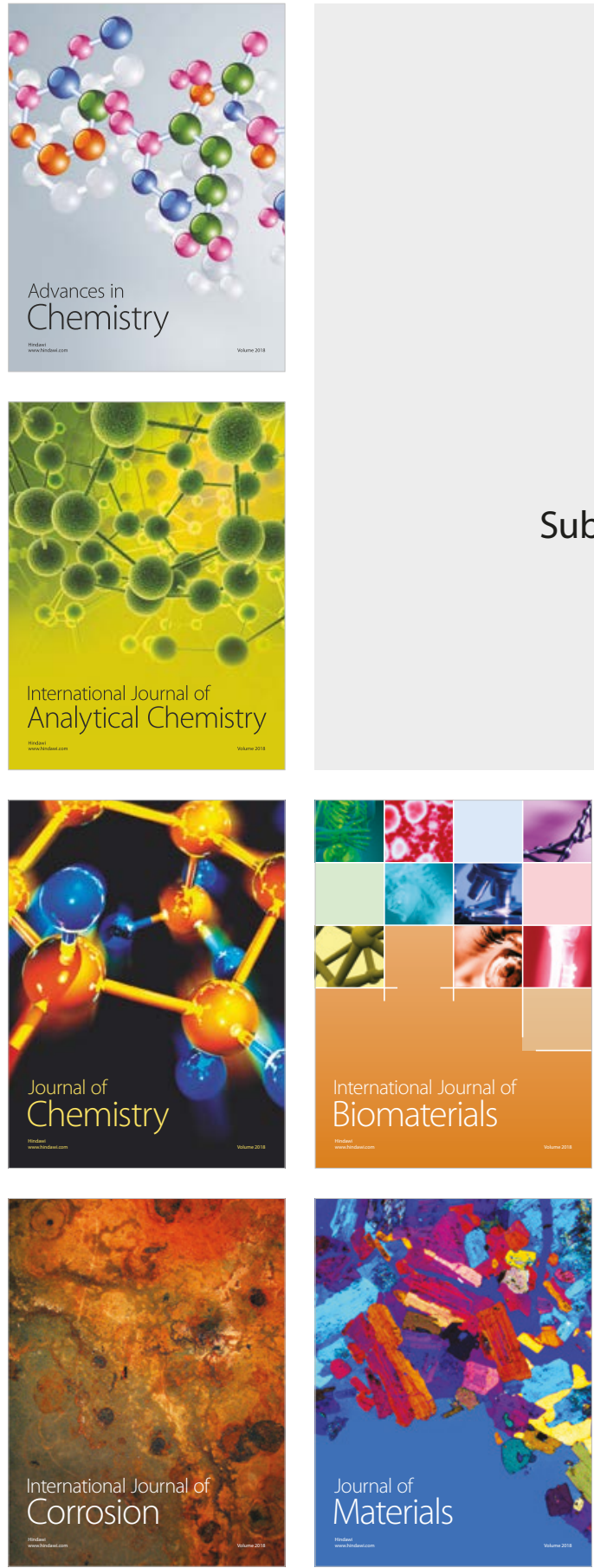

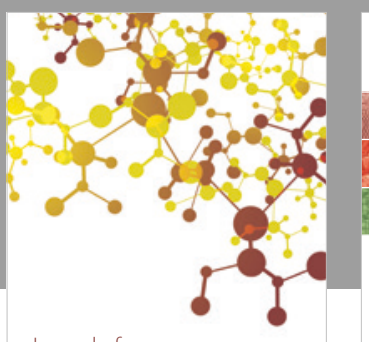

Journal of

Applied Chemistry
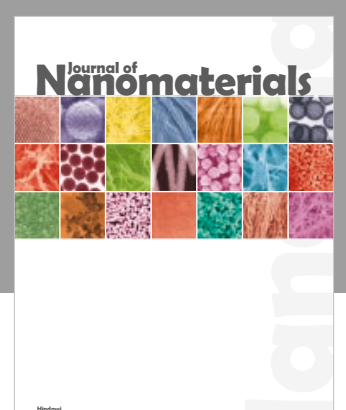

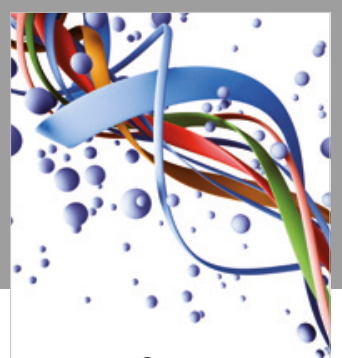

Scientifica

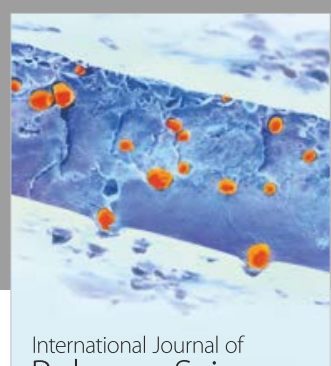

Polymer Science

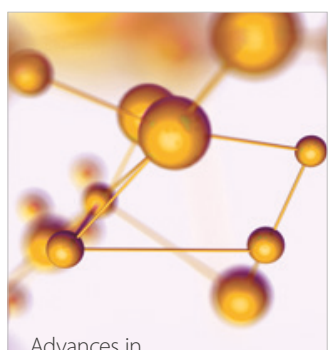

Physical Chemistry
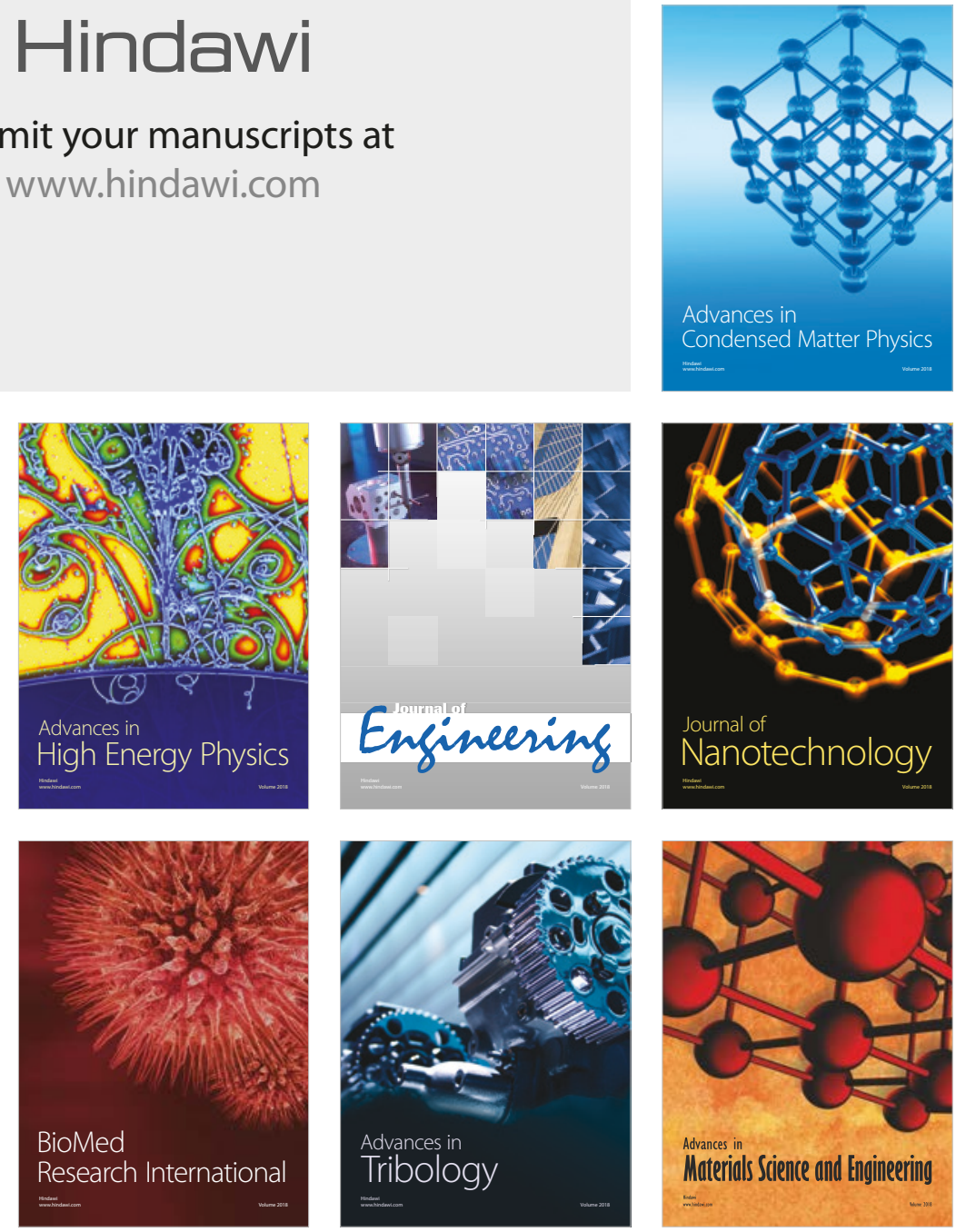